\title{
製品紹介
}

\author{
超臨界水熱合成装置について \\ 株式会社アイテック*1

\section{Supercritical Hydrothermal Synthesis System} \\ ITEC CO., LTD. \\ 4-132-1 Kannabe-cho, Sakai-Ku, Sakai, Osaka 590-0984, Japan
}

(Received July 18, 2009, Accepted August 6, 2009)

\section{1. はじめに}

近年，新素材としてナノ粒子が注目されており，そのナノ 粒子を合成する手法としての水熱合成は，バッチ式にて様々 に開発されてきた。 そのなかでも, 東北大学 WPI 原子分子 材料科学高等研究機構阿尻教授の技術である超臨界水熱合成 法は，従来法にない熱履歴による影響を受けない連続式で, 且つ新たな特性, すなわちナノ粒子合成, 形状制御, 酸化 · 還元反応制御, さらには, in situ熱処理といった特性が得 られ，広い有機・無機ハイブリッド素材分野への展開が期待 されている. 有機・無機ハブリッド材料としての半導体関連 部材 (パワーデバイス材料), 光学部材 (空間光制御部材), ディスプレイ部材（透明多機能膜）などは新規製品・サービ スを創造するものとしてその製造分野の多くの企業が事業化 を目指し，研究開発を行っている.

\section{2. 超臨界水ナノ粒子合成とは}

一般的にナノ粒子の作り方は粉砕（湿式, 乾式）と分子レ ベルの大きさから合成・成長させる方法があり，水熱合成は 分子レベルからの合成を水の高温高圧の超臨界の状態で行う 方法である. その原理は, 無機物の金属塩水溶液を瞬時に超 臨界状態にすると，金属塩水溶液として溶解していた無機物 がナノ粒子状態にて析出する. この状態で凝集を防止し, 新 しい性質を持たせるため, 修飾を行う方法を, 超臨界水熱合 成法という。

水は, 室温では, 電解質を溶解させる極性溶媒としての 78 と高い誘電率を有するが, 臨界点近傍では, 図 1 に示す ように，2～10 と無極性に近い状態となる．この状態では， 電解質としての金属塩を十分に溶解させることが出来ず，金 属酸化物や金属水酸化物は, 過飽和となり，ナノ粒子として 生成する.

また，超臨界近傍における 2 ～10 と無極性に近い誘電率の 状態は, 有機物の誘電率, ヘキサン 1.8 , ベンゼン 2.3 , アセ トン 20.7 と比較しても油の高い溶解度を有することを示し, 水と有機分子の均一相を形成することが可能である。つま り, 常温・常圧の水には溶解しない有機物質を溶解すること が可能なことを示す. 図 2 に示すように, 超臨界状態の水に 金属塩水溶液を瞬時に混合すると, 金属塩水溶液に溶存して

*1 $\overline{\mathbf{T}}$ 590-0984 大阪府堺市堺区神南辺町 4 丁 132 番 1

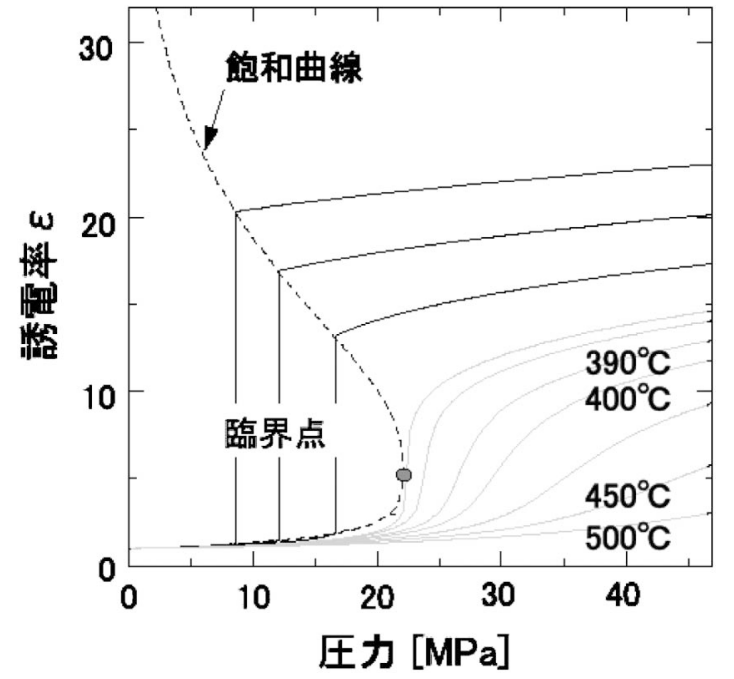

図 1 水の誘電率の温度 ·圧力依存性.

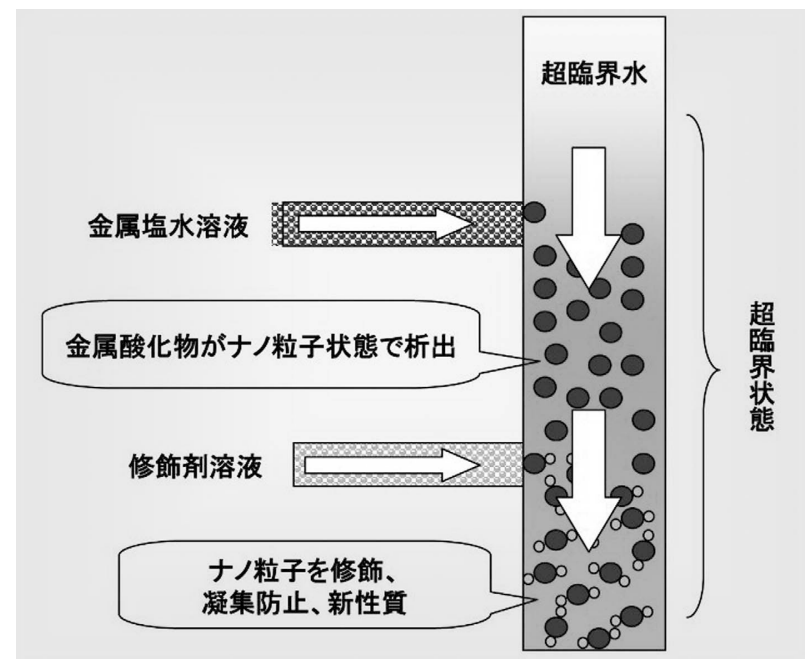

図 2 超臨界水のナノ粒子生成と有機修飾の過程.

いた金属塩が金属酸化物や金属水酸化物のナノ粒子状態で析 出する.ささらに無極性に近い超臨界状態で, 有機修飾剤溶液 を混合すると, 水と修飾剂分子の均一相を形成し, ナノ粒子 状態で析出した金属酸化物や金属水酸化物の周りに修飾する.

この修飾されたナノ粒子は，有機無機ハイブリッド合成さ れたものであり，新たな特性を持つ有機・無機ハイブリッド 

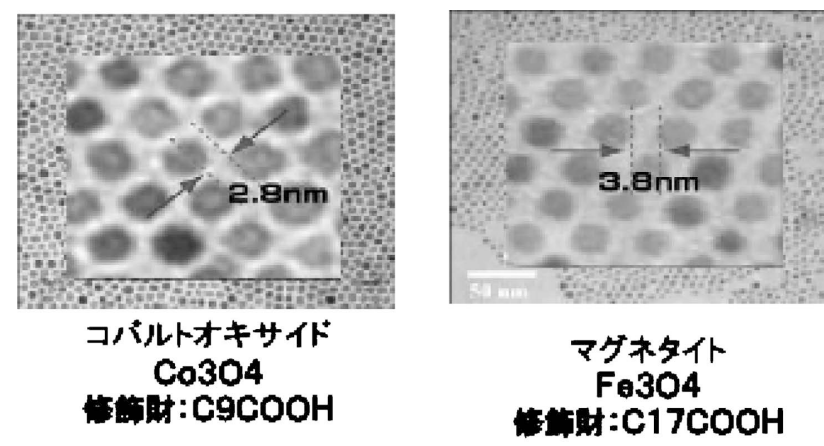

図 3 有機修飾の一例(J. Nanoparticle Res. 6. 9186 (2007)).

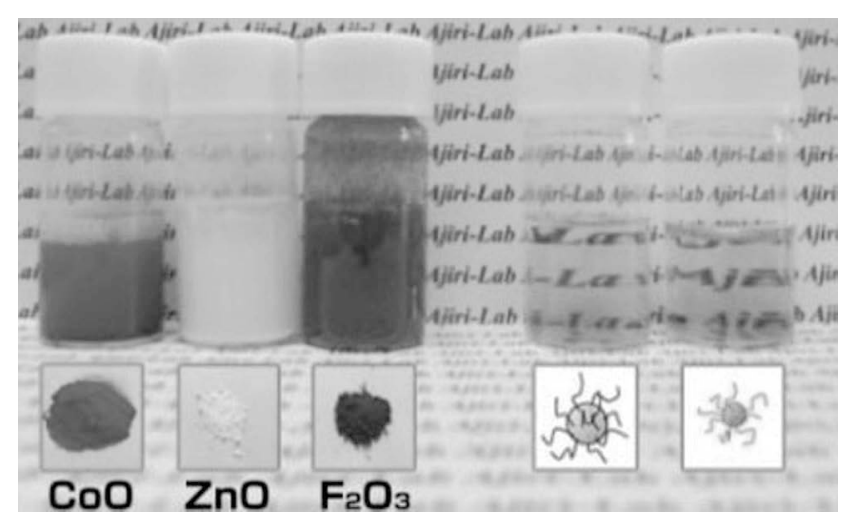

図 4 有機修飾の透明性 (Ajiri Lab).

素材として期待されている.

図 3 に有機修飾の一例を示すが，コバルトオキサイド，マ グネタイトの粒子が，有機修飾の効果として，自己秩序化さ れている. また，この粒子の間隔を測定してみると，ちょう ぞ有機分子の 2 倍となっている.つまりこの粒子の周りに は有機分子が規則正しく一列で配列し，修飾しているという 事を示している. 図 4 に有機修飾した粒子を溶液に分散させ た状態を示す。通常有機修飾しない場合は, 左の写真のよう に, 粒子が㠜集して, 絵の具を溶かした不透明のように分散 するが，有機修飾した粒子は透明の液になる，有機粒子がナ ノ粒子の表面に結合しているため, 有機溶剂と良好な親和性 を示し，このようなステンドグラスのような透明な液として 回収することが可能となる.

\section{3. 超臨界水ナノ粒子合成装置について}

超臨界水ナノ粒子合成は, 合成の均一条件を保持するため の定常化·安定化が, その製造装置化を図る上で, 重要とな る. つまり, 装置として, 一定の温度, 圧力, 流量, 滞留時 間, 均一混合など重要項目を満足する機器構成が必要となる.

\section{1 装置の構成}

超臨界水ナノ粒子合成装置は, 水, 金属塩水溶液および修 飾剤などの原料液を供給する供給ユニット，加熱・混合・反 応させる合成反応ユニット，高温より常温へ冷却する冷却ユ ニットならびにナノ粒子を回収する回収ユニットより構成さ れている.

その他に, 回収されたナノ粒子を含む溶液よりナノ粒子を 濃縮, 精製する機器も必要となる.

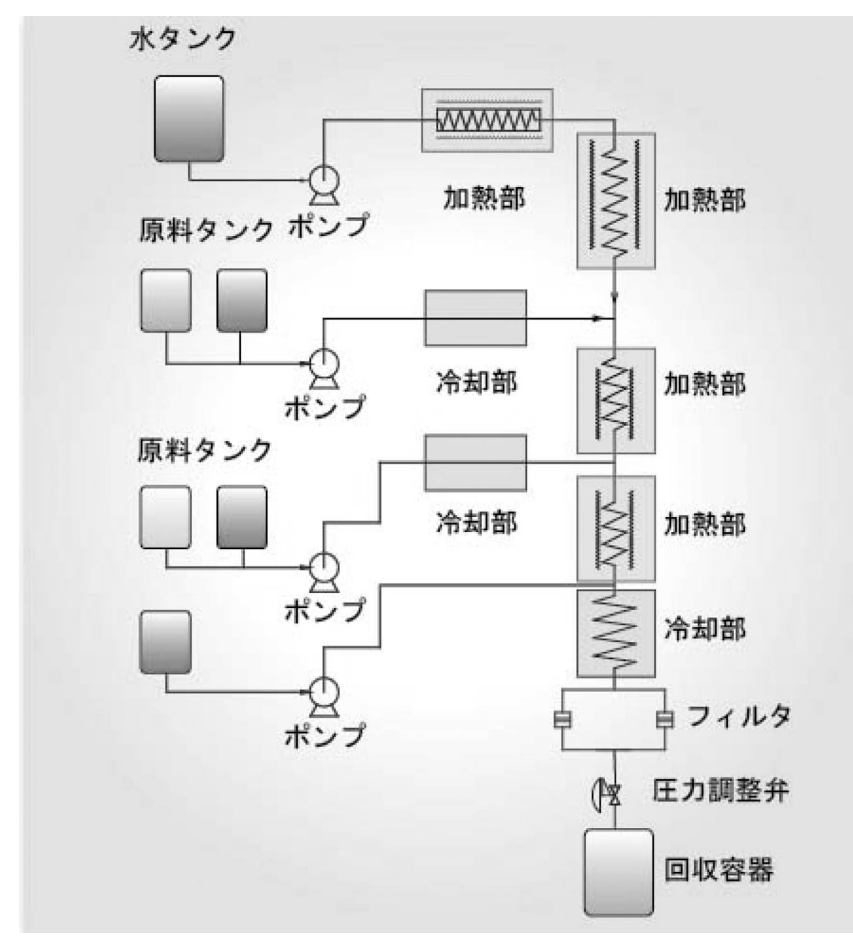

図 5 超臨界水ナノ粒子合成装置の基本フロー.

\section{2 基本フロー}

超臨界水ナノ粒子合成装置の基本フローを図 5 に示す.

水は, 供給ポンプにより, 超臨界に必要な圧力に加圧され て加熱部に導入され, 同じく超臨界に必要な温度近傍まで加 熱昇温し, 次の加熱部にて合成反応に必要な最終微調整を行 う. また, 金属塩水溶液は, 同様に超臨界に必要な圧力に加 圧されて, 超臨界状態にある水に混合される.この混合部 は, 金属塩水溶液が混合までに熱履歴を避けるため, 混合部 手前まで泠却されており，また瞬時に混合するように水と金 属塩水溶液の流路に工夫がされている，その下流にある修飾 するための混合部まで, ナノ粒子生成効率向上ための温度制 御と生成温度を保持するための加熱器がある. 修飾剂は, 金 属塩水溶液同様に超臨界に必要な圧力に加圧されて, 超臨界 状態にある水と金属塩水溶液によりナノ粒子の合成された状 態に, 混合される. 混合部の温度は, 修飾条件にあった温度 にするための加熱器により調節されている．この混合部もま た, 混合までの熱履歴を避けるため, 混合部手前まで冷却さ れており，瞬時に混合するように流路に工夫がされている. 修飾されたナノ粒子は, 安定した修飾を得るための温度制御 と生成温度を保持する機能を持つ加熱器を経由して, 冷却器 により常温まで泠却される.ナノ粒子合成を瞬時に停止する 必要がある場合は, 冷却器の直前で直接ポンプにて加圧した 水により冷却することも可能である.

常温に冷却されたナノ粒子を含む溶液は，フィルタにより ナノ粒子を回収するが，フィルタで捕集されなかったナノ粒 子は, 反応系内圧力調整のため設置された背圧弁を通過し, ナノ粒子を含む溶液として回収する。閉塞性や, 磨耗性のあ るナノ粒子をの場合は, 回収ラインに設置された系内圧力調 整のため設置している背圧弁の閉塞や磨耗対策として, この フィルタは必要である. 


\section{3 超臨界水ナノ粒子合成試験機（MOMI 超-mini）}

超臨界水ナノ粒子合成は, 原材料の組合せ, 濃度, $\mathrm{pH}$, 圧力, 温度など多くの条件を試験にて見出す必要があり, 簡 易的に，且つ容易にある程度の条件を絞れる試験機の提供を 要望された。試験機では, その重要な要素である急速昇温 度, 反応部の温度制御, 修飾条件, ナノ粒子回収法など, ガ スクロなどの分析機と同様に, 操作が容易な卓上型となって いる. 試験機は, 図 6 に示すように, 加熱炉の温度を反応部 の反応温度に設定し, その雾囲気温度下に再加熱ヒーターを 設置したことにより, 再加熱部の放散熱は加熱炬に有効利用 され, 熱損失が最低限に抑えられ, また再加熱ヒーターは加 熱炉内に設置されたため外部熱変動を受けにくく, 粗加熱な がら温度制御性が向上し, 最重要な温度制御が必要な混合部 の手前に設置された微調整ヒーターの精密な制御性が可能と なっている.

図 7 に超臨界ナノ粒子合成試験機（MOMI 超-mini）の基 本フローを示すが, 前述の装置のフローと, 機能的には同じ であるが，簡易的に，且つ操作が容易となるよう，最小限の 機器構成となっている. 温度 ・圧力の応答性が速い流通式の ため, 連続流通の状態で, 原材料の組合せ, 濃度, $\mathrm{pH}$, 圧

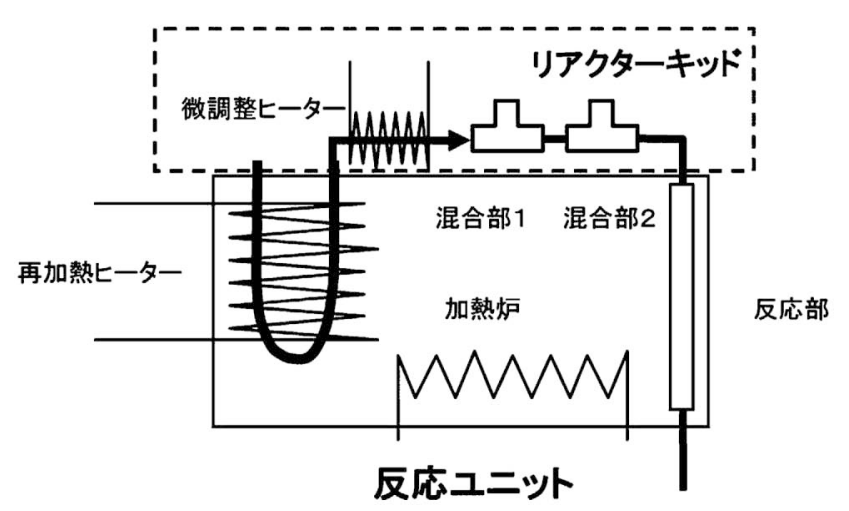

図 6 試験機の反応部ユニット.

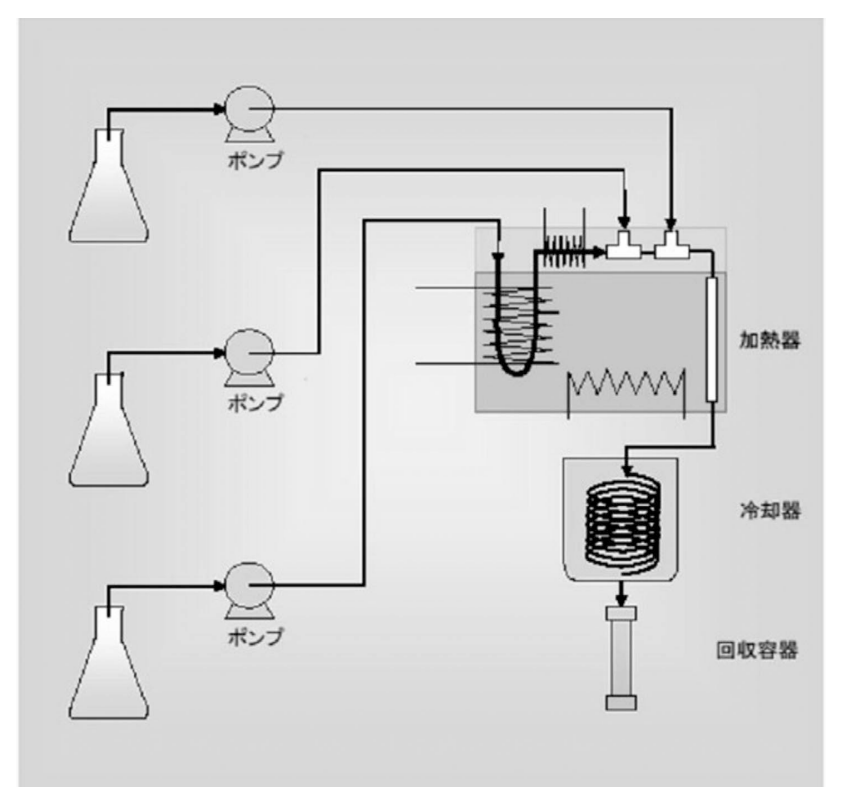

図 7 超臨界水ナノ粒子合成試験機の基本フロー.
力, 温度など多くの要素条件を変化させ，短時間での数多く の試験データ採取が可能となる.

この試験機により，大よその合成条件が解明した時点で, 最終のより事業化のための熱・物質収支のデータ採取に使用 するため, 前述の装置が必要となる.

また，原材料の組合せなどの，試験条件変更の場合，コン タミを避けるため, 金属塩水溶液および修飾剤の混合部を簡 単に交換可能にするためのリアクターキットを採用し, 反応 部も交換容易な構造となっている.

\section{4. まと め}

現在, 生産機としても使用可能な超臨界水熱合成装置, 通 称 MOMI 超（図 8）は，基本仕様としてナノ粒子製造量0.1 〜 トン/年, 大型生産機としての通称 MOMI 超-Giga は, ナノ粒子製造量 $5 \sim 50$ トン/年の生産規模を視野に入れてい る.

試験機（通称 MOMI 超-mini）（図 9）では，コンビナト リアルケミストリーとして使用されることも視野に入れ, 超 臨界合成に限定せず，連続した亜臨界反応としての使用も可 能で，幅広く，ナノ複合金属合成試験，有機合成試験なぞへ の発展もまた可能である.

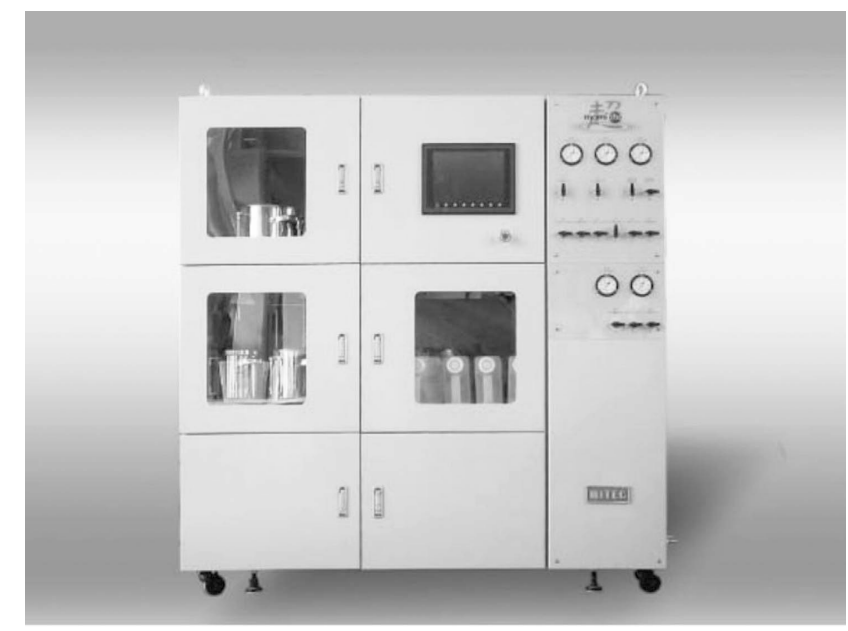

図 8 超臨界水ナノ粒子合成装置.

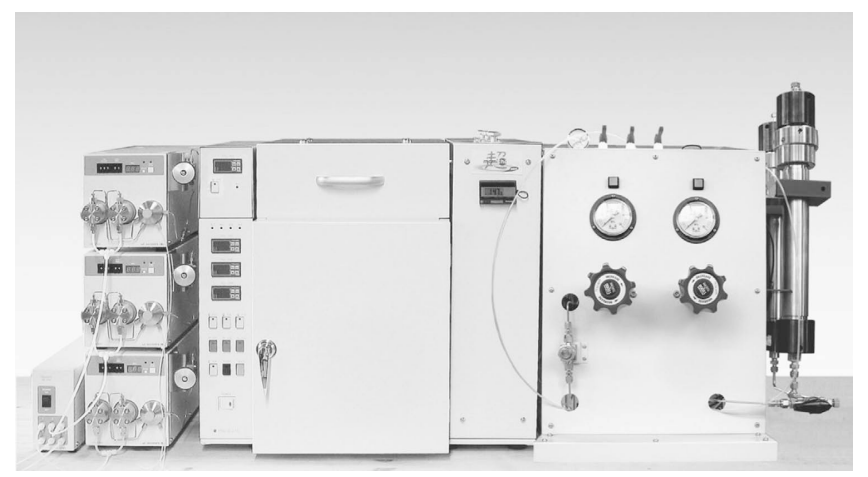

図 9 超臨界水ナノ粒子合成試験機（MOMI 超-mini）. 